\title{
UMA ABORDAGEM MATEMÁTICA DA INFORMAÇ̃̃O: A TEORIA DE SHANNON E WEAVER - POSSÍVEIS LEITURAS
}

\author{
Alzira Tude Sá 1 \\ Instituto de Ciencia da Informação da UFBA \\ alziratude@gmail.com
}

\begin{abstract}
Resumo
Este artigo busca analisar o conceito particular de informação ditado pela Teoria Matemática da Comunicação , rever a visão matematizada de Shannon e Weaver, tangenciando pelo tempo espiralado que antecede e vai desde a sua aparição nos idos de 1949, o seu "apagamento" por conta de outras teorias que lhe sucederam, seu retorno à cena pela via de estudos desenvolvidos por alguns pesquisadores que se debruçam sobre questões que envolvem a informação, bem como a sua contribuição para a Ciência da Informação e outras áreas do conhecimento, atentando para a diversidade dos discursos e os conceitos operativos que oscilam neste percurso.
\end{abstract}

Palavras-chave: Teoria matemática da comunicação. Teoria matemática da informação.

\section{A MATHEMATICAL APPROACH TO INFORMATION: THE THEORY OF SHANNON AND WEAVER - POSSIBLE READINGS}

\begin{abstract}
This paper analyzes the particular concept of information dictated by the Mathematical Theory of Communication, reviewing mathematized view of Shannon and Weaver, tangential to the spiral time before and going since its appearance back in 1949 his "erasure" on behalf of other theories that succeeded him, his return to the scene by means of studies carried out by some researchers who focus on issues involving information as well as its contribution to information science and other fields of knowledge, focusing on the diversity of discourses and operational concepts ranging this route.
\end{abstract}

Keywords: Mathematical theory of communication. Mathematical theory of information.

\section{INTRODUÇÃO}

Não se pode prescindir do contexto em que ideias e protagonistas florescem quando se pretende fazer uma revisão histórica de conceitos e teorias. E ademais, não se pode deixar de

1 Profa. Dra Departamento de Fundamentos e Processos Informacionais do Instituto de Ciência da Informação da UFBA.

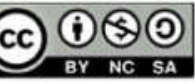

Esta obra está licenciada sob uma Licença Creative Commons Atribuição 4.0 Internacional (CC BY-NC-AS 4.0). 
ter em mente premissas não excludentes tais como a descrição dos acontecimentos, sua evocação e reconstrução pelo olhar contemporâneo.

Por assim pensarmos, este trabalho busca trazer o conceito particular de informação ditado pela Teoria Matemática da Comunicação ${ }^{2}$, rever a visão matematizada de Shannon e Weaver (1975), tangenciando pelo tempo espiralado que antecede e vai desde a sua aparição nos idos de 1949, o seu "apagamento" por conta de outras teorias que lhe sucederam, seu retorno à cena pela via de estudos desenvolvidos por alguns pesquisadores que se debruçam sobre questões que envolvem a informação, bem como a sua contribuição para a Ciência da Informação e outras áreas do conhecimento, atentando para a diversidade dos discursos e os conceitos operativos que oscilam neste percurso.

Nos anos 40 do século 20, anos de guerra, uma verdadeira explosão científica e tecnológica ocorre no mundo capitalista. Como consequencia, uma exacerbada massa documental passa a ser produzida num contexto não adaptado a tal realidade, desde o tratamento dado às informações produzidas, no que tange ao seu armazenamento e recuperação, ao arcabouço teórico que dava sustentação a área e aos recursos humanos disponíveis para lidar com o volume de informação produzido. Nessa época, o pensamento passou a ser conduzido pela crença de que só a tecnologia poderia dar conta desse universo informacional e é nesse contexto que emerge a ideia de informação como um recurso estratégico, econômico e político a ser gerenciado.

Regido pelo capitalismo, os EUA, em pleno confronto com o desenvolvimento cientifico e tecnológico que grassava na Rússia, buscava se projetar como país investidor e produtor de ciência e tecnologia. Tais blocos hegemônicos investiam na produção científica e tecnológica na ânsia de garantir-lhes a supremacia e o poder ambicionados.

Conforme atesta Seracevic (1996), nos anos 50 e 60, com o apoio do Congresso e de agências governamentais, e uma forte adesão de empresas privadas, os Estados Unidos investem em programas estratégicos que visam o gerenciamento das informações produzidas, tanto nas áreas de ciência e tecnologia quanto em outros campos do conhecimento. Por conta desses investimentos e programas desenvolveu-se uma moderna indústria da informação que, numa escalada ininterrupta, caracteriza o que hoje se cognomina de sociedade da informação.

Dentre as cabeças pensantes voltadas para a solução dos problemas causados pela produção em massa de informações e a necessidade premente de seu gerenciamento, destaca-

${ }^{2}$ Como essa teoria tem sido denominada também de Teoria da Informação, vamos adotar a designação que lhe foi dada pelos seus autores - Teoria Matemática da Comunicação- TMC, e sua sigla, quando a ela nos referirmos, mantendo a nominação que lhe é dada pelos autores citados. 
se no cenário, a figura de Vannevar Bush considerado como responsável pelo desenvolvimento das inovações tecnológicas do seu país, com objetivos militares, que, além de detectar os problemas, aponta para soluções, segundo declaração de Seracevic (1996, p. 42):

Bush identificou o problema da explosão informacional - o irreprimível crescimento exponencial da informação e de seus registros, particularmente em ciência e tecnologia. A solução por ele proposta era a de usar as incipientes tecnologias de informação para combater o problema. E foi mais longe, propôs uma máquina chamada MEMEX, incorporando (em suas palavras) a capacidade de associar idéias, que duplicaria "os processos mentais artificialmente.

No mesmo diapasão acrescenta Barreto (2007) que:

[...] ainda nesse tempo, Norbert Wainer publicou "Cybernetics", sobre a teoria matemática da informação e Vannevar Bush publicou "As we may think" (Como nós pensamos), apontando os problemas decorrentes do volume e do valor e da informação liberada após a segunda guerra mundial. (BARRETO, 2007, p.19-20).

Nesse artigo, Bush (1945 apud BARRETO, 2007, p. 19-20), aponta para o problema em torno da informação em ciência e tecnologia e para os obstáculos aos quais estavam sujeitas a sua organização e repasse à sociedade. Através de um "ajuste tecnológico" objetivava tornar acessível a informação produzida de um acervo que crescia a cada dia de forma avassaladora, ajustar os sistemas de classificação e indexação existentes à época, bem como os processos de armazenagem e recuperação da informação, sugerindo que os mesmos deveriam ser operacionalizados por associação de conceitos, "como nós pensamos".

Questões essenciais tornaram-se ordem do dia tais como a análise subjetiva dos documentos e a criação de linguagens documentárias para a recuperação da informação e sua disseminação, colocadas em função do contexto político e econômico que premia pelo desenvolvimento científico e tecnológico com finalidades e aplicações militares e ainda mais num momento em que havia uma emergência de novos campos ou refinamento/substituição de conexões interdisciplinares de antigos campos.

Diante dessa nova realidade em que a informação passou a ser considerada como insumo para o desenvolvimento, em que se estabelece um elo entre informação, pesquisa e desenvolvimento e a ela é agregado um valor político e econômico, urgia que soluções fossem encontradas para sanar as dificuldades apresentadas e atender á demanda social por acesso às informações produzidas. A criação e inovação de sistemas, técnicas e máquinas despontou como provável solução em busca da qual empenharam-se governos, associações, sociedade civil, como atesta Seracevic (1996, p. 44), quando re refere à repercussão do artigo de Vannevar Bush (1945):

Nos anos 50, uma massa crítica de cientistas, engenheiros empreendedores começaram entusiasticamente a trabalhar o problema e a solução apontados por BUSH.Nos anos 60, esse trabalho tornou-se uma atividade relativamente ampla, bem 
financiada e organizada, que deu origem a debates estimulantes e a acalorada argumentação acerca das melhores e mais adequadas soluções (técnicas, conceitos, sistemas, etc) (SERACEVIC, 1996, p. 44).

Como fruto desse espírito de época, a natureza interdisciplinar e a responsabilidade social com a transmissão da informação passaram a figurar como características de um campo do conhecimento cuja construção se avizinhava, a Ciência da Informação. O seu alvorecer, segundo Pinheiro (2005) "é apontado por alguns autores e sinalizado por seus eventos propulsores, em torno de 1950", apesar de ter, como registro oficial a $2^{\mathrm{a}}$ reunião no Georgia Institute of Technology, realizada no período de 12 e 13 de abril de 1962. Afirma a autora que essa nova ciência se preocupava não só com:

[...] o fluxo da informação ou transferência da informação [mas ] desde a sua origem, isto é, a geração, num processo que a aproxima do conhecimento, ou como os cientistas produzem informação, o que inclui o ciclo da pesquisa e criação. E mais, quais as consequências nos indivíduos e comunidades que a utilizam, no processo cognitivo de aquisição e transmissão de informação, além das questões de organização e processamento [...] (PINHEIRO, 2005, p. 18).

Na construção desse campo científico não estavam implícitas apenas questões de ordem política, mas questões epistemológicas refletidas na escolha do objeto, dos métodos, técnicas, escolhas não "desinteressadas", mas permeadas pela luta de poder que a ela subjaz A busca por um conceito de informação, objeto desse campo, ganhou relevância nesse período de pós-guerra por conta da disseminação global do uso da rede de computadores, afirma Capurro (2007), e como a informação não só é como tem sido ao longo do tempo e essencialmente nesse tempo, um objeto de interesse e estudo de uma variedade de áreas do conhecimento, fazia-se necessário uma conceituação que a definisse, que lhe desse identidade. E por pensar assim alerta o autor para a seguinte questão:

Para uma ciência como Ciência da Informação é sem dúvida importante a forma como seus termos fundamentais são definidos e assim como em outros campos, na CI a questão sobre como definir informação é freqüentemente levantada (CAPURRO, 2007, p. 149).

Antes de sairmos em busca de teorias que visam explicitá-la, partimos de princípios advogados por Bourdieu (2004) referentes à sua construção. Para ele todo objeto da ciência é fruto de um sistema de relações construídas propositadamente e toda prática científica implica pressupostos teóricos que procuram explicar o mundo e refletir formas de percepção que, análogas ou contrastantes, buscam espelhar a realidade. Acrescenta ainda que "[...] por mais parcial e parcelar que seja um objeto de pesquisa, só pode ser definido e construído em função de uma problemática teórica que permita submeter a uma interrogação sistemática os aspectos da realidade colocados em relação entre si pela questão que lhes é formulada" (BOURDIEU, 
2004, p. 45).

Ao estabelecer uma relação simbiótica entra política e sociedade e ao acreditar na impossibilidade de uma ciência neutra e de uma imparcialidade dos sujeitos, Bourdieu (1988, p. 86), acredita que: “[...] toda teoria contém, de forma implícita ao menos, uma teoria da percepção do mundo social e estas teorias da percepção do mundo social se organizam segundo as oposições muito análogas aquelas existentes no mundo natural".

As teorias, para o autor, são apenas ideologias justificadoras de uma forma particular de competência científica e seus protagonistas, pessoas engajadas e com interesses em comum ligados ao campo e à luta pela sua existência. O campo estará, portanto, sempre a mercê de mudanças e nesse sentido, para que se possa compreender o pensamento de um determinado autor nele inserido, é preciso que se elucide não só as suas ideias como o universo intelectual no qual circula.

Quanto à sua produção cientifica, para compreendê-la, conforme Bourdieu (1997, p. 13), faz-se necessário que inicialmente se compreenda a produção, o campo da produção, a relação entre o campo no qual ela se produz e o campo em que a obra é recebida ou, mais

precisamente, a relação entre as posições do autor e do leitor em seus respectivos campos. Chama a atenção para o fato de que devemos atentar sempre para as diferentes contribuições

que um determinado autor oferece, para os métodos adotados, as ideias que tenta veicular, por considerar impossível “[...] diante da dimensão infinita da realidade social”, que qualquer um deles consiga estabelecer considerações exaustivas e definitivas. É por essa via que partimos ao encontro de Shannon e Waever (1975), da teoria por eles formulada.

\section{SOBRE SHANNON E WAEVER: O PERCURSO ATÉ A TEORIA}

Todo esse percurso traçado e considerações tecidas foram no sentido de trazer à luz, nesse trabalho, o papel representado por Shannon e Waever (1975), na construção das ideias e teorias que buscavam e ainda buscam um sentido para o objeto informação, atentando para o contexto político e social, cientifico no qual estavam inseridos, para suas biografias, fatores que definem e interferem no fazer ciência.

Como foi abordado anteriormente, após a Segunda Guerra começaram a multiplicar-se as tecnologias de transferência de informação sem que nenhuma teoria se voltasse para a quantificação da informação que precisava ser transportada, como por exemplo, a transmissão de mensagens telegráficas com maior velocidade, com fins militares. Claude Shannon e Warren Weaver, nesse tempo, eram engenheiros da Companhia Telefônica de Nova York e estavam 
preocupados em transmitir o maior número possível de mensagens, no menor espaço de tempo, ao menor custo operacional e com a menor taxa de ruído, segundo estudos desenvolvidos por Guaraldo (2007, p. 17). Criaram uma teoria. A Teoria Matemática da Comunicação, por outros cognominada de Teoria da Informação, demonstrando que cada canal de comunicação, seja ele um fio telegráfico, fio telefônico, cabo axial ou outros, tem uma velocidade limite característica. Uma teoria que segundo Araújo (2009), pela primeira vez enunciou um conceito científico de "informação".

Claude Elwood Shannon nasceu no dia 30 de abril de 1916, em Peoskey, Michigam, Estados Unidos e faleceu em 24 de fevereiro de 2001. Seu pai foi juiz, aficcionado pela matemática e sua mãe, professora e diretora de uma escola pública, na cidade de Gaylord, onde Shannon passou os primeiros 16 anos de sua vida. Desde cedo se interessou por objetos mecânicos criando engenhocas para seu divertimento, como um telégrafo com fios de arame farpado, um barco controlado por rádio desenvolvendo, desde cedo, um gosto por jogos mentais e resolução de criptogramas inspirado na literatura de Edgar Allan Poe, em especial no livro "Escaravelho do Diabo" (PINEDA, 2006, p.16).

Ainda segundo Pineda (2006), quando criança Shannon também apreciava jogos que exigiam destreza física, principalmente aqueles que exigiam raciocínio, em graus elevados, atributos que o levaram a ser movido por uma espécie de curiosidade e pelo prazer de solucionar problemas, distanciado de interesse por prêmios, reconhecimento ou retorno financeiro.

Nutria admiração pelos cientistas Thomas Edison, Newton, Darwin e Von Neumann, tendências e escolhas que iam conformando o perfil do futuro bacharel em Matemática e Engenharia Elétrica, formado em 1936, aos 20 anos de idade. Mestre em Engenharia e doutor em Matemática, pelo Massachusetts Institute of Technology - MIT, foi engenheiro e professor tendo trabalhado, desde os anos 40 e por mais de 15 anos, como pesquisador do Bell Laboratórios.

Movido pela curiosidade, pelo espírito inquieto de pesquisador, envolvia-se em atividades consideradas como "divertidas "como foi por ele considerada a elaboração da sua dissertação de mestrado "A symbolic analysis of realy and switching circuits" considerada, que, segundo Pineda (2006), representa um marco na Ciência da Computação.

Seus estudos possibilitaram o avanço do computador, impactando na tecnologia da comunicação e informação, ao passar do plano de um processamento de cálculo analógico para digital e, ao aplicar a álgebra booleana, permitiu que o computador deixasse de ser apenas uma simples calculadora, dando passos à frente das propostas de Vannevar Bush do qual foi assistente. 
Dentre os projetos dos quais participou destaca-se o Projeto $\mathrm{X}$, desenvolvido nos Laboratórios Bell, voltado para o desenvolvimento do rádio e sua aplicação militar o que resultou no emprego de técnicas de criptografia e criptologia da voz humana, método descrito na Teoria da Comunicação dos Sistemas de Sigilo. Vale ressaltar que Shannon, nesse projeto, interagiu com Alan Turning, um dos cientistas mais reconhecidos na área e nesse tempo de guerra. Antes dessa teoria eram usados métodos analógicos de distorção de ondas sonoras o que era considerado pouco eficaz para o entendimento do que era transmitido. O Sistema X, descrito matematicamente, propunha a quantificação de ondas sonoras chegando a colaborar com os estudos linguísticos desenvolvidos por Chomsky, podendo ser considerado como uma versão preliminar da Gramática Gerativa Transformacional, na visão de Pineda (2006, p. 2).

A busca da solução para problemas militares fez com que uma rede de relações e influências fosse estabelecida entre destacados cientistas da época mesmo estando, cada um deles, em busca de soluções específicas para as questões tecnológicas e comunicacionais apresentadas. Nesse bojo destacam-se Shannon e Waever, que publicam, em 1949, uma obra intitulada $A$ Mathematical Theory of Communication, na qual consideram a transmissão da

informação como um fenômeno estatístico, quantificável. A Shannon é conferido o direito de ser considerado como o "pai do bit" por ter mostrado como medir a quantidade de informação e ter dado a preferência ao sistema de numeração binário. Esses estudos favoreceram o desenvolvimento de novas tecnologias de comunicação que impactaram, diretamente, nas áreas de informática e telecomunicações. Além da Teoria Matemática da Comunicação, que o consagrou, Shannon tem uma vasta e diversificada obra sobre tecnologia e comunicação. ${ }^{3}$

As contribuições de Warren Weaver à concepção da Teoria Matemática da Comunicação são inegáveis por dar à informação uma dimensão física e quantificável, independente do seu conteúdo, dos emissores e receptores. Como Shannon, Waever nasceu nos Estados Unidos, na cidade de Reedsburg, Wisconsin, em 17 de julho de 1894, onde ingressou na universidade. Iniciou sua carreira, como professor, no Throop College de Pasadena, nos anos de 1917 e 1918 e no California Institute of Technology permaneceu durante os anos de 1919 e 1920. Morreu no ano de 1978, no dia 24 de novembro (PINEDA, 2006).

Como professor retorna à Universidade de Wisconsin e leciona matemática por doze anos, assumindo o cargo de diretor do Departamento de Matemáticas, durante os anos de 1928

\footnotetext{
3 A relação dessas obras podem ser encontradas nesse endereço <endereçohttp://www2.research.att.com/ njas/doc/shannonbib.html.>. Seria impossível listá-las no corpo do trabalho devido a quantidade de textos escritos e publicados pelo autor.
} 
a 1932. Ficou célebre por ter criado a expressão biologia molecular para designar o trabalho conjunto da biologia, física e química na busca do conhecimento das moléculas que atuam no interior das células. Destaca-se também por ter escrito o memorando Translation, em 1949, propondo técnicas estatísticas no campo da teoria de informação que poderiam ser usadas para permitir que os computadores traduzissem textos, automaticamente, de um idioma para outro. Por esta razão é considerado como a primeira pessoa que propôs o emprego de computadores eletrônicos para a tradução de idiomas.

Sua projeção pode ser avaliada pelos cargos ocupados. Foi nomeado presidente da National Academy of Sciences, em 1954 e diretor de diversas fundações destacando-se a Rockefeller Foundation's Natural Science Division, onde permaneceu no cargo por longos anos, de 1932 a1955. Como diretor da Fundação Rockfeller garantiu generosas doações para a pesquisa, bem como possibilitou que as primeiras publicações dos teóricos daquele período fossem publicadas.

\section{A TEORIA MATEMATICA DA COMUNICAÇÃO: ASPECTOS E CONCEITOS}

Juntos, Shannon e Waever criam uma teoria inspirando o aparecimento de uma diversidade de estudos sobre a mesma e seu objeto, a informação. Capurro (2003) considera que sua essência postula que há algo, um objeto físico que um emissor transmite a um receptor, mas não denomina esse objeto transferido como informação, mas como mensagem, signos que devem ser reconhecidos pelo receptor sob certas condições ideais. Num outro diapasão, Pellegrini advoga que $(2009$, p.13) “[...] sua origem está na solução de problemas técnicos de transmissão de sinais uma vez que a abordagem dos sistemas ocorre pelo viés da engenharia."

Na visão de Pereira (1999) a TMC é uma teoria que visa transmitir o maior número possível de mensagens, no menor espaço de tempo ao menor custo operacional, com a menor taxa de ruído. Mas deixemos falar os seus autores que assim a explicitam:

\footnotetext{
O problema fundamental das comunicações é reproduzir em um determinado ponto, tão exato quanto possível, uma mensagem originada em um outro ponto. Frequentemente as mensagens contêm significado, isto é, elas se referem ou são correlacionadas a algum sistema de entidades físicas ou conceituais. Estes aspectos semânticos da comunicação são irrelevantes ao problema de engenharia. A faceta significativa é aquela em que a mensagem real tenha sido selecionada entre um grupo de possíveis mensagens. O sistema deverá ser projetado de modo a operar com qualquer das possíveis seleções a serem efetuadas, e não unicamente com aquela que realmente foi escolhida, posto que isto é desconhecido quando concebemos ou projetamos o sistema (SHANNON; WAEVER, 1975, p. 33).
} 
E elucidando ainda mais, acrescentam os autores que "Nesta teoria, a palavra informação é utilizada com um sentido especial, que de maneira alguma devera ser confundido com o de seu uso generalizado. Especificamente informação não deve por equivoco, ser compreendida como significado" (SHANNON; WAEVER, 1975, p. 9). Informação para eles deve ser compreendida como a medida de liberdade de alguém para escolher, quando está diante do processo de selecionar uma mensagem, não se relacionando ao que na verdade é dito, mas, ao que poderá se dizer. Representa a redução da incerteza ao se obter a resposta a uma questão formulada, não levando em conta os aspectos da semântica da comunicação que para os autores são considerados como irrelevantes.

O fato de Shannon ter trabalhado como criptógrafo na II Guerra Mundial, no entanto, não deve tê-lo tornado alheio à questão da semântica, desde quando uma mensagem codificada, para um sujeito que não tenha a "chave" para a sua decodificação, será uma mensagem desprovida de sentido. Mas para um criptógrafo, que elaborou a "chave" ou a tem, a mensagem terá, certamente, um conteúdo decifrável e nela a informação.

Considerando que existem problemas no "vasto campo de Comunicação", os autores os apresentam em três níveis:

Nível A.Com que exatidão é possível os símbolos da comunicação serem transmitidos? (Este é o problema técnico); Nível B. Com que precisão os símbolos transmitidos transferem o significado desejado? (Este é o problema da semântica); Nível C.Com que eficiência o significado recebido afeta o comportamento, a conduta do receptor em relação a finalidade desejada e prevista? (Este é o problema da eficiência) (SHANNON; WAEVER, 1975, p. 4).

O problema técnico refere-se ao transporte físico da materialidade da informação: som, altura da voz, tipo e impressão de papel, etc., a questão semântica, relaciona-se ao significado, ao desligamento do sentido da materialidade, e quanto à eficiência, é levado em conta o seu papel no processo de comunicação e seu poder de convencimento, pois quem transmite uma informação a outro almeja uma mudança de comportamento e provocar uma reação.

Shannon e Waever, para muitos, constroem uma teoria voltada só para o primeiro nível: para o transporte físico da informação. Mas, a seção 3, do texto que apresenta a Teoria Matemática da Comunicação, A Inter-Relação dos Três Níveis dos Problemas de Comunicação, dedica-se a avaliação e justificativas sobre questões abordadas nas seções anteriores. Quanto ao restrito uso pela teoria, do Nível A, assim se referem:

[...] os progressos alcançados nos problemas do Nível A serão capazes de contribuir para a solução daqueles nos Níveis B e C [e acrescenta, considerando] que a teoria matemática é extraordinariamente generalizada em seu escopo; que é fundamental em relação aos problemas que aborda; que é de simplicidade e poder clássicos nos resultados que atinge (SHANNON; WAEVER, 1975, p. 26). 
Ao apresentar os problemas de comunicação que ocorrem no Nível A, concebem um sistema assim representado:

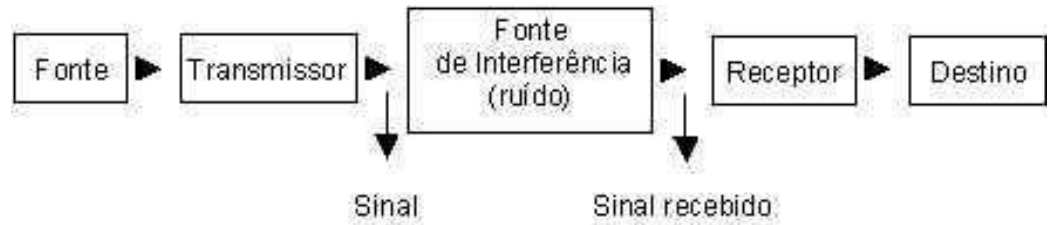

Nesse processo

[...] a fonte de informação seleciona a mensagem desejada dentre um grupo de mensagens possíveis [...], O transmissor transforma a mensagem em sinal que é enviada através do canal de comunicação existente entre emissor e o receptor [e o] receptor é uma espécie de transmissor em reverso, pois transforma o sinal transmitido em mensagem e envia a mensagem para o seu destino (SHANNON; WAEVER, 1975, p. 7-8).

Os autores chamam a atenção para o fato de que, no processo de transmissão, pode ocorrer que "partículas indesejáveis" ao sinal, não previstas pela fonte de informação, possam ser acrescentadas causando distorções no som, na imagem ou mesmo erros de transmissão, considerados como "deformações da fidelidade”, os ruídos. Como elementos levados em conta na comunicação da informação, pela $\mathrm{TMC}$, os ruídos, por serem distorções que afetam a mensagem, acabam por provocar uma incerteza indesejável. No entanto, teóricos contemporâneos destacam que o ruído também pode ser considerado como um fator positivo, por levar, muitas vezes, o emissor a modificar, corrigir a mensagem, contribuindo para o aperfeiçoamento da mesma.

Outro conceito que fundamenta essa teoria é a entropia, uma apropriação das ciências exatas. A justificativa é dada pelos autores quando afirmam ser "[...] natural que a informação seja medida pela entropia nessa teoria desde quando ela é análoga ao volume de liberdade de escolha que se tem para conseguir as mensagens" (SHANNON; WAEVER, 1975, p.1). A ideia de entropia está relacionada a uma situação singular, à medida do "grau de revelia, de embaralhamento, da mudança ou troca de posição.

Uma explicação para tal conceito nos é dada por Araujo (2009, p. 194) ao afirmar que na TMC:

\footnotetext{
A informação é definida como uma medida da incerteza - não como aquilo que se poderia informar. Diante de uma pergunta com apenas duas opções de resposta, o grau de informação seria da ordem de 50\%. Diante de uma pergunta com mais opções (uma situação com maior grau de incerteza), o valor informativo aumenta. Em situações de alta previsibilidade, o grau informativo é baixíssimo.
}

Ao trazer das ciências exatas os conceitos de entropia e probabilidade a TMC considera a informação como uma entidade "da ordem da probabilidade, sendo a entropia um de seus 
atributos" o que, segundo Araujo (2009, p. 194) torna ainda mais clara a característica que a particulariza, a quantificação da informação.

A repercussão da TMC no meio científico e a sua apropriação por outras áreas do conhecimento não foi tão bem acatada por Shannon, chegando a provocar um afastamento da teoria por ele desenvolvida. Diz Pineda (2006, p. 19) que "[...] a distorção de seus conceitos quando aplicados noutras disciplinas o incomodava. Some-se a isto a aversão a linhas de pensamento místico-religiosas que era a reação que o conhecimento da Teoria da informação provocava em muitos".

Levanta a hipótese de que outros motivos poderiam estar ligados a tal afastamento como disputas internas entre grupos de estudos que tinham opiniões divergentes sobre o uso que deveria a ela ser dado. O grupo ligado à TMC - Teoria Matemática da Comunicação que defendia o seu uso por outras áreas e o PGIT- Grupo Profissional da Teoria da Informação que primava pelo uso exclusivo em assuntos tecnológicos.

Diante de tal cenário, de divergentes opiniões, tão próprio do campo científico, torna-se de fácil compreensão a análise feita por Capurro (2003) sobre o êxito ou predomínio de um paradigma científico e o seu condicionamento a fatores sociais e sinergéticos, quando estuda os paradigmas epistemológicos que influenciaram a Ciência da Informação. Ele afirma que:

\section{[...] as visões e paixões que suportam por assim dizer os processos cognitivos, constituem o cerne mesmo, em parte latente e em parte explícito, de todo campo científico, pois o êxito ou o predomínio de um paradigma científico está sempre em parte condicionado às estruturas sociais e aos fatores sinergéticos, incluindo eventos fora do mundo científico, cujo efeito multicausal não só é difícil de prever, como também de analisar a posteriori. (CAPURRO, 2003, Não paginado).}

Uma variedade de estudos, análises e apropriações da TMC tem aportado a posteriori. Por ser uma teoria que dá prioridade ao primeiro nível da comunicação, Shannon e Waever tornam possível a construção de um referencial teórico para os problemas relacionados com o transporte físico da informação, que, na perspectiva de Araujo (2009, p.193), “[...] é a partir dessa 'brecha', dessa proposição de uma forma 'científica' de estudo da informação, que se constrói o projeto de uma ciência da informação".

Como essa teoria tem sido analisada e apropriada, a posteriori, é o que vamos tentar demonstrar ao apresentar fragmentos de discursos e considerações de teóricos e pesquisadores contemporâneos da área da Ciência da Informação e de outras áreas do conhecimento. 


\section{A TMC NA VISÃO DE ALGUNS PENSADORES CONTEMPORÂNEOS}

A opção pela cronologia dos trabalhos publicados que apresentam visões sobre a TMC, deve-se ao entendimento de que, ao traçar esse percurso, pode-se estar contribuindo para demarcar, no tempo, algumas das diferentes modalidades críticas e posicionamentos sobre a teoria desenvolvida por Shannon e Waever (1975).

Publicado em 1995, o texto escrito por Gilda Maria Braga (1995), Informação, ciência da informação: breves reflexões em três tempos, reflete sobre o conceito de informação fundamentada no pensamento de teóricos que, por partirem de princípios os mais diversos, nos levam à compreensão da complexidade do objeto da Ciência da Informação. Da Teoria Matemática de Shannon à informação atrelada ao documento, a autora chega a considerar que o fenômeno informação se aproxima do caos e que os sistemas de recuperação da informação, por serem vistos como complexos, aproximam-se dos novos paradigmas da ciência relacionados ao caos e a complexidade.

Diferentes teses e dissertações, segundo Braga (1995), têm enfocado essa conceituação como ponto de partida para uma melhor compreensão do fenômeno informação que ainda apresenta ambigüidades, lacunas, imprecisões e grandes zonas de incerteza Para ela,

\footnotetext{
Outras noções possíveis de informação passam por Shannon \& Weaver, Brillouin, Wiener, Mattessich, Saracevic, Goffman, Buckland e vários outros autores, enfocando a informação como redutora de incertezas, entropia negativa, fator de homeostase, força básica, utilidade pública, algo que é transmitido em um processo de comunicação, uma “coisa” (BRAGA, 1995, Não paginado).
}

Quando o foco da discussão se volta para a TMC, considera que Shannon quebrou a igualdade, a identidade entre a informação e o documento "[...] ao retirar da informação o seu suporte físico obrigatório e ao transportá-la por um canal qualquer, como o ar, por exemplo [...]” (Braga, 1995, Não paginado), estabelecendo a partir daí uma nova identidade da informação com o domínio do quantitativo e da probabilidade. Já em 1953, observa que a quantidade de informação está ligada não ao que se diz, mas ao que se pode dizer, ou seja, está ligada a um pré-conhecimento do conteúdo da mensagem. E acrescenta: "Informação sobre algo que conhecemos é inútil como informação" (Braga, 1995, Não paginado). Para ela Shannon não só desvinculou a informação de um suporte físico, como também estabeleceu a noção da mensagem distinta da informação e a noção da dependência do estado mental do receptor.

Enfatiza que na visão de Shannon, a informação não depende de uma instituição física ou de um suporte material, mas de um emissor, um receptor, um canal, um processo de 
comunicação, e pode ser quantificada. Gradativamente, a noção de quantidade de informação, tão debatida por shannonistas e semanticistas na década de 60 , ficou esquecida, talvez até porque, para uma Ciência da Informação então emergente, o mais importante era uma nova visão de informação, e não tanto a possibilidade de sua mensuração, apesar de ter sido este o aspecto que mais atraiu, inicialmente, a atenção da comunidade científica como um todo.

No mesmo tempo de Braga (1995), e anos depois, em 2002, a pesquisadora Lena Vânia Ribeiro Pinheiro escreve dois artigos, apontando para as correntes de pensamento e teóricos da Ciência da Informação, nesses 30 anos de existência. Relata sobre os estudos e discussões teóricas sobre o objeto do seu fazer - a informação, desde a Teoria Matemática da Informação até os dias de Saracevic, assinalando, como promete, "os eventos anunciadores de seu nascimento." Dentre eles o evento datado de 1948; o trabalho publicado por Norbert Wiener, Cybernetics or control and communication in the animal and the machine, no ano seguinte, 1949; o lançamento da Teoria Matemática da Comunicação ou Teoria da Informação de Shannon e Weaver e em 1951 a formulação, por Bertalanffy (1968), da Teoria Geral de Sistemas -TGS.

Pinheiro (2002, p. 9) ao atentar para o fato afirma que:

Os dois primeiros trabalhos, tendo como preocupação as tecnologias, não são apenas eventos anunciadores, mas vão repercutir, em níveis de intensidade diferenciados, dependendo da disciplina da Ciência da Informação e da ótica dos pensadores e teóricos da área. A teoria da informação, sobre cuja repercussão há polêmica, ainda que originalmente voltada para um problema eminentemente técnico, de otimização de transmissão de sinais de telefonia, cria conceitos, tais como ruído, entropia e redundância, importantes para os sistemas de recuperação da informação, mesmo que, diferentemente da Ciência da Informação, não considere os aspectos semânticos e até mesmo influências da informação (ou de relevância).

Apesar de concordar com a idéia de que essas teorias contribuíram para que uma visão mecanicista de sistemas de informação tivesse uma ascendência na Ciência da Informação, sua colaboração não pode ser negada. E quanto à Teoria da Informação ou Teoria Matemática da Comunicação, de Shannon eWeaver, diz a autora, que essa teoria traz "[...] importante contribuição ao conceito da informação, ainda que sua origem esteja na solução de problemas técnicos de transmissão de sinais, na comunicação" (PINHEIRO, 2002, p. 10).

Ciente da complexidade do conceito de informação, Capurro $(2003,2007)$ tem desenvolvido estudos que buscam não dar conta, mas situar histórico e conceitualmente o termo e a sua apropriação pela Ciência da Informação "[...] na perspectiva de suas relações interdisciplinares". Quando assim procede, tanto no texto Conceito de Informação (2007) quanto Epistemologia e Ciência da Informação (2003) dá o devido lugar à TMC, considerando que é de dentro de um paradigma físico que surge a Ciência da Informação. E assume como 
tese

[...] que a ciência da informação nasce em meados do século XX com um paradigma físico questionado por um enfoque cognitivo idealista e individualista, sendo este por sua vez substituído por um paradigma pragmático e social [...] por uma epistemologia social (CAPURRO, 2003, Não paginado).

Quando analisa a TMC tomada como modelo na Ciência da Informação, chama a atenção para o fato da "[...] analogia entre a veiculação física de um sinal e a transmissão de uma mensagem, cujos aspectos semânticos e pragmáticos intimamente relacionados ao uso diário do termo informação são explicitamente descartados por Shannon" (CAPURRO, 2003, não paginado). No entanto, chama a atenção para o curso do desenvolvimento da teoria de Shannon e Waever, para a intenção de nela serem incluídas as dimensões semânticas e pragmáticas, sinalizada na Teoria, Seção 3, assunto abordado, anteriormente, neste trabalho. Atenta o autor para o fato de que

Torna-se evidente que, no campo da ciência da informação, o que esse paradigma exclui é nada menos que o papel ativo do sujeito cognoscente [...], do usuário, no processo de recuperação da informação científica, em particular, bem como em todo processo informativo e comunicativo, em geral. [...] Não é de se estranhar que os limites dessa metáfora hajam conduzido ao paradigma oposto, o cognitivo (CAPURRO, 2003, não paginado).

Carlos Alberto Ávila Araújo (2009) é outro autor que se propõe, num artigo publicado na revista Ciência da Informação, a apresentar correntes teóricas da Ciência da Informação, a fazer uma revisão de literatura e analisar o conceito de informação elaborado por cada uma delas no sentido de identificar, datando historicamente, as suas contribuições e a participação dessas teorias na consolidação de um paradigma positivista para o campo. Assim como Pinheiro (2002), Araujo (2009, p.193) afirma que "É bastante comum encontrar, na área de CI, a indicação da importância da TMC de Shannon e Weaver, apresentada em 1948 e publicada em 1949, como um prenúncio ou mesmo inauguradora do campo", e realça a ideia de que essa foi a teoria que pela primeira vez enunciou um conceito científico de informação $[. .$.$] ". Como$ argumento, afirma que :

Ao "limpar" o conceito de suas dimensões de significação e de relação social, Shannon e Weaver descartam a subjetividade como elemento componente da informação, tornando possível uma aproximação dela enquanto fenômeno objetivo, independente dos sujeitos que com ela se relacionam e portanto passível de ser estudada"cientificamente (ARAUJO, 2009, p. 193).

E acrescenta que é a partir dessa "brecha", dessa proposição de uma forma "científica" de estudo da informação, que se constrói o projeto de uma Ciência da Informação, cuja aplicação da TMC se dá nos estudos da recuperação da informação.

No campo da CI, a aplicação mais decisiva se dá no campo dos estudos em recuperação da Informação. Entre os conceitos centrais desse campo destacam-se os 
de revocação e precisão, que operam na lógica da probabilidade e da entropia, na busca de um ideal de recuperação que contemple uma quantidade boa de itens (exaustividade) e, ao mesmo tempo, traga itens relevantes (especificidade) (ARAUJO, 2009, p. 194).

Reafirma Araujo (2009, p. 194) que só interessa o impacto imediato dessa teoria, nos estudos a respeito da transferência de informação, pelo fato de que nela "São elaboradas fórmulas para prever quanto texto pode ser transmitido em cada formato, a partir do repertório de diferentes grupos, respeitando a capacidade de cada canal, entre outros aspectos". Quanto à mensuração e transporte da informação, relembra que a aplicação de técnicas estatísticas antecedem à TMC e que, numa vertente diferenciada, a Bibliometria já se voltava para a recuperação da informação, desde os anos 20, quando padrões de regularidade, em ítens informacionais, eram observados e quantificados através de leis que foram, empiricamente, desenvolvidas por Lotka, Bradford, e Zipf. Conclui reafirmando o que outros estudiosos defendem, que a TMC e sua perspectiva matemática do transporte de informação, apesar das críticas a que esteve sujeita, continua na pauta das discussões. Fundamenta seu argumento citando teóricos que assim procedem:

A perspectiva matemática do transporte de informação continua atual, apesar das várias críticas recebidas, como se pode ver em teorizações como a de Saracevic, para quem a CI estuda "os problemas da efetiva comunicação do conhecimento" (1996, p.47); de Buckland (1991), que conceitua a informação como "coisa"; e de Le Coadic, que confir rma, após 80 anos desde a formulação da primeira lei quantitativa no âmbito da CI, "a existência, no campo da informação, de regularidades, distribuições e relações mensuráveis universais” (ARAÚJO, 2007, p. 221).

\subsection{OUTRAS POSSÍVEIS LEITURAS}

A informação tem sido entendida de formas, as mais diferenciadas, pelos mais diversos grupos de atores que com ela se relacionam e a TMC, com sua particular visão da informação, tem conseguido permanecer na pauta das discussões sobre informação, entabuladas nos longos 63 anos de sua existência. No entanto, atenta Araujo (2009) para o fato de que as teorias que buscam dar conta da informação vão confluindo para um resgate da sua dimensão material e cultural, da sua dimensão pragmática que foram, em sua opinião, descartadas pela Teoria Matemática. Outros olhares resgatam a TMC e dela se apropriam como o fazem alguns pensadores e áreas do conhecimento que realçam a importância e a sua permanência na pauta das discussões contemporâneas sobre o objeto informação e principalmente sobre as questões que envolvem as tecnologias da informação e comunicação.

Morin (1977), sociólogo, pensador e critico da cultura e da ciência, teórico do pensamento complexo, ao considerar que a informação é um conceito físico e novo que surge 
no campo tecnológico, dedica, na sua obra $O$ Método $1:$ A natureza da natureza, no capitulo II, A física da informação, estudos sobre a "informação shannoniana." Faz uma releitura da TMC trazendo exemplos que demonstram os conceitos teóricos propostos por Shannon, considerando que a "[...] informação está necessariamente associada à redundância e ruído" e que sua degradação por esses fatores é um problema “inerente á comunicação" (MORIN,1977, p.2 77).

Quanto à questão do sentido da mensagem transmitida, Morin (1977, p. 278) afirma que "a informação shannoniana chega a ser internamente muda ou cega quanto à sua significação, à qualidade, ao valor, ao alcance da informação para o receptor." Apesar de atentar para o fato de que um bit, na verdade, "não é uma unidade de sentido", busca na literatura, num momento vivido por Tristão e Isolda, a demonstração dessa mudez e cegueira a que se refere:

\begin{abstract}
Isolda espera o regresso de Tristão; sabe que numa vela branca anunciará o regresso do seu amante, uma vela negra, a sua morte ; para ela os dois ramos desta alternativa são equiparáveis. Ora que se passará na informação shannoniana com as alternâncias de esperança e de desesperança de Isolda, com sua s emoções e com sua espera, com amor desmedido, com o espctro da morte? (MORIN, 1977, p. 278).
\end{abstract}

Para Morin (1977, p. 278), "Quando no mar infinito surgir uma vela branca ou negra, o observador shannoniano factura: um bit", e é sob esse ângulo que ele vê e considera o conceito de informação da TMC, como insensato, pois é "cega para o sentido", para o interesse pela "verdade da informação." No entanto, pondera que essa ausência de medida do sentido e alcance da informação, não interfere na utilização da TMC nas comunicações desde quando:

De resto, a teoria de Shannon elaborou bem o quadro relacional no qual a informação deve ser procurada e encontrada, [...] a relação entre o emissor da mensagem e o receptor, relação que pode ser psicológica, afectiva, profissional, etc. [...] A questão do sentido é assim remetida para o contexto [...] Sendo extremamente lúcida quanto á ameaça exterior (MORIM, 1977, p. 279).

Se tal teoria tem a lucidez de perceber a ameaça exterior que pode interferir na integridade da informação, como por exemplo, os ruídos, ela é "surda" para aqueles que podem advir do interior, dos ruídos interiores capazes de destruir o sentido da mensagem. Morin (1977, p.279) acaba por afirmar que, se a TMC é "Cega para o sentido, só pode ser cega para a falta de sentido".

Não poderíamos deixar de trazer uma leitura da TMC vinda da área da Comunicação. Elegemos Um estudo dos aspectos da pesquisa norte-americana em comunicação: Primeira metade do Século $X X$, de autoria de Tamara de Souza Brandão Guaraldo, que analisa uma série de modelos teóricos de Comunicação, dentre eles o modelo de Shannon \& Weaver (1975).

Conforme a autora, o advento das tecnologias da comunicação de massa impulsionou os cientistas sociais a pesquisarem os efeitos que os novos meios poderiam causar nos 
indivíduos. A partir dos anos 20 tornaram-se populares os estudos que se voltavam para os “efeitos diretos, uniformes e imediatos" produzidos nas pessoas, pelos meios de comunicação. Nesse tempo, afirma Guaraldo (2007, p. 20), “[...] a 1a Teoria da Comunicação do século: a Teoria das Balas Mágicas foi dada a conhecer sendo superada quando se iniciaram as pesquisas empíricas e os estudos propuseram uma série de modelos de comunicação [...]” e dentre eles, cita a TMC como uma das teorias "[...] que tiveram grande influência nos estudos da comunicação até nossos dias [por estarem, seus autores] preocupados em transmitir o maior número possível de mensagens no menor espaço de tempo ao menor custo operacional com a menor taxa de ruído" (GUARALDO, 2007, p. 20).

Citando Beltrão (1986), a autora destaca a importância da Teoria da Informação para o trabalho jornalístico quando a ela se refere:

Quando o jornalista redige a notícia colocando no lead o máximo de informações e deixando 'no pé' os pormenores de menor importância que podem ser cortados quando há falta de espaço - consciente ou inconscientemente - ele está aplicando o princípio da quantificação da informação (BELTRÃO, 1986, p. 178 apud GUARALDO, 2007, p. 19).

O que confirma, segundo a autora, que a relação espaço-tempo, no processo de comunicação é importante, desde quando o espaço da notícia é delimitado em caracteres e laudas, a velocidade do locutor na locução, o tempo da sonoplastia e das imagens, bem como o casamento entre texto e imagem na $\mathrm{TV}$, para que não haja redundância desnecessária, a redundância no texto radiofônico, elementos que devem ser calculados e selecionados pelo jornalista.

Para Guaraldo (2007, p. 20) o "Modelo de Shannon \&Weaver seguiu sendo um modelo linear de Comunicação, uma mensagem que parte da fonte até o destinatário, uma teoria da transmissão mais adequada à engenharia da comunicação." Enfatiza, no entanto, que a pesquisa norte-americana da primeira metade do Século XX “[...] inferiu traços básicos da comunicação social: a importância do meio, a relação dos componentes sociais para produzir uma resposta perante os estímulos do contexto e a transmissão da herança social [...]”.

Por conta do surgimento das novas tecnologias de comunicação, mediadas por computadores em rede, e mais precisamente com a popularização da Internet, uma área que ganhou vulto, como tema acadêmico, nas últimas décadas, foi a Educação à Distância, cuja mudança conceitual tem se alargado. Nesse tempo vem surgindo novos métodos educacionais, inovadoras concepções de material didático, as relações entre os sujeitos tem se caracterizado de forma diferente, principalmente, novas formas de relacionamento e apropriação do conhecimento pelos sujeitos sociais. 
A Internet tem sido cada vez mais utilizada para apoiar e complementar o ensino tradicional. Para fundamentar o uso de teorias de Comunicação, e em especial da TMC, em alguns aspectos da EAD, Pimentel e Andrade (2000) escrevem um artigo, considerando que, “[...] será suficiente a caracterização do processo de comunicação de forma semelhante à antiga caracterização de Aristóteles, cujo esquema é tricotômico, ou seja: a pessoa que fala; o discurso que pronuncia; e a pessoa que escuta. (PIMENTEL, 2000; ANDRADE, 2000, não paginado).

Propõem, no entanto, uma substituição ou seja, que “Ao invés de 'discurso, será preciso aqui generalizar para processo de comunicação [...] uma extrema simplificação do modelo de Shannon-Weaver" Ao proporem tal substituição confirmam que a TMC fornece à EAD, instrumentos úteis fundamentados no que diz Humberto Eco $(1997$, p. 4) sobre a complexidade dos processos comunicacionais e sobre a utilidade de se individualizar a relação comunicacional:

[...] não porque os fenômenos de comunicação mais complexos sejam redutíveis à passagem de um sinal de uma máquina a outra, mas porque é útil individuar a relação comunicacional, na sua dinâmica essencial, ali onde se delineia com maior evidência e simplicidade, sugerindo-nos a construção de um modelo exemplar" (ECO, 1997, p. 4 apud PIMENTEL, 2000; ANDRADE, 2000, Não paginado).

Mesmo admitindo que os fenômenos comunicacionais não se resumam a uma passagem de um sinal de uma máquina a outra como preconizam Shannon e Waever, concordam Pimentel e Andrade (2000, não paginado) que a Educação à Distância:

[...] só é possível porque existem tecnologias que possibilitam estabelecer este processo de comunicação mesmo quando alunos e professores encontram-se fisicamente distantes - é possível graças às tecnologias de telecomunicação tais como livro, telefone, rádio, televisão e redes de computadores.

Admitem, no entanto, a possibilidade de haver um empobrecimento da informação introduzida pelas tecnologias de telecomunicações, os ruídos, previstos pela TMC e que tal argumento tem sido usado em detrimento da Educação a Distância, chamando a atenção para o fato de que o ser humano atribui significado à informação que lhe chega aos sentidos, o que põe por terra tal alegação. Concluem Pimentel e Andrade (2000, Não paginado) que "[...] mesmo um vídeo com qualidade ruim será de grande validade se o conteúdo deste vídeo for significativo para o aprendiz". Ou seja, esse empobrecimento não invalida o processo de ensinoaprendizagem. A utilização da Teoria da Informação, como os autores a designam, serviu-lhes de parâmetro para classificar os sistemas educacionais em função do tempo de comunicação presencial e a distância e em função do tipo de comunicação estabelecido entre professores e alunos.

O uso da TMC não foi, no entanto, considerado adequado por alguns campos, e por alguns autores, como na Cartografia. Esta não adequação, segundo Firkowski (2002) é alegada: 
[...] em função de que no meio de comunicação, objeto da Cartografia, não ocorre perda de informação mas pelo contrário, nestes sistemas durante sua leitura e observação são suscitadas impressões e mesmo relacionamentos que não foram de forma consciente, projetados pelo cartógrafo.(FIRKOWSKI, 2002, p. 34).

Por outro lado, Bjorke (1996, apud FIRKOWSKI, 2003), enxerga uma relação da TMC com a Cartografia na fase do projeto cartográfico, no momento em que se faz necessário averiguar a eficiência na comunicação de uma representação cuja produção é fruto de um trabalho interativo. Considera o conceito shannoniano de entropia apropriado para aplicações no nível sintático da comunicação cartográfica. Para Firkowski (2002) que desenvolveu uma tese baseada na TMC,os aspectos mais importantes da teoria, aplicáveis à cartografia, são a:

[...] determinação da função expressa a similaridade observável ou presente nos dados e a determinação do valor(s), do parâmetro(s) para esta função de similaridade [que é] representada pela avaliação de um conjunto de dados cartográficos, segundo algum ponto de vista, expressão de alguma condição de critério cartográfico para comunicação de dados (FIRKOWSKI, 2002, p. 41).

E numa outra direção, propondo uma aproximação dos aspectos conceituais presentes na Teoria matemática da comunicação e a Comunicação Social, Pellegrinni (2009) escreve um artigo com o objetivo de reduzir

[...] a formalização matemática em favor de uma explanação verbal que esclareça sem corromper os fenômenos, centrando-se nos conceitos mais relevantes para a Comunicação Social [ além de] uma aproximação do pesquisador de comunicação social geralmente, oriundo das humanidades, de tão fundamental obra paraa compreensão do momento presente (PELLEGRINI, 2009, p.11).

Por se dizer inserido num mundo que vive uma transição tecnológica, uma revolução digital, em uma sociedade cognominada de sociedade da informação, em rede, considera que é inegável que a base dessas transformações e dessa transição

[...] está na crescente mudança das tecnologias analógicas de comunicação e no armazenamento de informação para as tecnologias digitais [e que ] Os fundamentos científicos de tal mudança foram estabelecidos em 1948, no livro do matemático e engenheiro americano Claude Elwood Shannon, chamado Teoria matemática da comunicação (PELLEGRINI, 2009, p. 12).

Na perspectiva de Pellegrini (2009), o livro de Shannon é um clássico das convergentes áreas da Informática e Telecomunicações, pelo fato de ter definido conceitos e modelos que ainda permanecem atuais apesar de terem atravessado as décadas de tecnologia analógica. A TMC, para ele, permanece, em plena era digital, como um guia para cientistas e engenheiros, no desenvolvimento de tecnologias de comunicação.

Ao dar ênfase a alguns aspectos da teoria shannoniana, destaca: a quantidade da informação que tem uma relação direta com o desconhecimento que ela elimina entre fenômenos ou mensagens possíveis, aspecto que dotou a composição da mensagem de uma natureza estatística; a entropia que para o autor, “[...] revela uma das grandes vantagens em se 
trabalhar com bits, [desde quando] o registro ou transmissão se torna mais resistente aos efeitos da distorção ou do ruído em função de sua entropia ser menor" (PELLEGRINI, 2009, p. 20 21); o uso dado por Shannon à palavra bit que permanece até hoje; a questão da capacidade do canal que é um aspecto bastante importante da TMC e que pode ser comprovado com a necessidade, cada dia mais premente, dos usuários da Internet e pelo uso cotidiano de informações que exigem mais e mais uma maior capacidade de canal, como demonstra:

\footnotetext{
Pesquisas escolares não buscam mais apenas textos escritos e fotos: procuram-se também vídeos sobre os temas desejados, com resoluções cada vez maiores. Comunicações pessoais já não se limitam ao e-mail, mas passam a fazer uso de sistemas de voz sobre IP e web conferences. Mesmo o trânsito intenso de material menos nobre como e-mails com piadas ou pornografia tendem a abandonar sua forma verbal escrita ou de imagens estáticas em favor do audiovisual com alta definição (PELLEGRINI, 2009, p. 20-21).
}

Ao tentar aproximar a TMC da Comunicação Social, Pellegrini (2009, p. 19) conclui que "A obra de Shannon é tão vasta e tão presente no contexto tecnológico que se vive que urge a demanda pela atualização de sua importância histórica e de uma ressignificação de sua participação na história da Comunicação.” Acrescenta que

[...] a obra de Shannon também conseguiu extrapolar os limites da especialização: com a popularização do computador e as novas tecnologias de comunicação, as ideias de Shannon penetraram no repertório do cidadão médio junto com os bens de consumo informatizados (PELLEGRINI, 2009, p.19).

\section{FECHANDO AS PÁGINAS}

Trilhar um percurso da recepção da TMC ou TI através da pluralidade de leituras e pontos de vista, deixou à mostra a experiência ressignificada dessas leituras no presente, as marcas das condições históricas nas quais foram produzidas, ficando patente para nós a possibilidade sempre presente, de transformação e atualização permanente de teorias e métodos que buscam dar conta da realidade.

Ficou patente também que o eixo mediador da permanência e atualização da TMC, na pauta dos estudos da informação e comunicação, está representado pelos sujeitos leitores, constituintes de campos do conhecimento, junto às suas condições históricas, políticas e sociais, bem como pelas diferentes contribuições que os autores ofereceram a esses campos, representadas pelas variadas formas de sua apropriação.

Percebe-se também que a diversidade dos enfoques de leituras acabam por demonstrar que as ferramentas de análise das teorias, de cada momento, nelas se projetam, deixando entrever as diferentes tendências interpretativas que, em cada época, moldaram os julgamentos e apropriações da teoria shannoniana. À mercê, caem muitas vezes, essas leituras, na 
unilateralidade, ressaltando ora os seus aspectos positivos, outras vezes os aspectos negativos, em busca de uma compreensão mais profunda do objeto analisado, a informação.

A forma particular de exercer a competência científica de Shannon e Weaver determinou a visão matematizada da informação que legaram. Numa homologia com o momento histórico por eles vivido, criaram uma teoria que buscava atender às necessidades vitais de comunicação da época, teoria que vem confluindo até nossos dias e para que tal fato seja melhor compreendido, retomamos Bourdieu que advoga ser necessário para a compreensão de um determinado autor ou teoria que se elucide não só as suas ideias, como o universo intelectual no qual circula.

Quanto aos princípios básicos preconizados pela TMC que regem o processo da comunicação, em sua descrição mais primária, um emissor, um receptor, um canal, há segundo a pesquisadora Gilda Braga (1995), uma conceituação quase tácita de que informação implica processo de comunicação e partindo desse princípio questiona:

Existiria alguma informação que não passasse pelo processo de comunicação?’[...] E uma vez que tal processo estabelece uma relação que também é parte do processo em si mesmo, haveria uma informação - ou melhor, uma noção de informação que rompesse com tal tríade e se configurasse de forma totalmente distinta? (BRAGA, 1995, Não paginado).

Assim pensavam Shannon e Waever. 


\section{REFERENCIAS}

ARAÚJO, C. A. A. Correntes teóricas da Ciência da Informação. Ciência da Informação, v.38, n.3, p.192-204, set/dez., 2005.

BARRETO, A. A. Uma história da ciência da informação. In: TOUTAIN, Lidia Maria batista Brandão. Para entender a Ciência da Informação. Salvador: Edufba, 2007. (Sala de aula, $6)$.

BELTRÃO, L.; QUIRINO, N. O. Subsídios para uma teoria da comunicação de massa. São Paulo: Summus Editorial, 1986.

BRAGA, G. M. Informação, ciência da informação: breves reflexões em três tempos. Ciência da Informação, v. 24, n. 1, 1995. Disponível em:

$<$ http://revista.ibict.br/ciinf/article/view/612/614>. Acesso em: 14 maio 2018.

BOURDIEU, P. Coisas ditas. São Paulo: Editora Brasiliense, 1990.

BOURDIEU, P.; CHAMBOREDON, J. C.; PASSERON, J. C. Aruptura. In: Ofício do sociólogo: metodologia da pesquisa sociológica. 5. ed. Petrópolis: Vozes, 2004. p. 23-44.

BOURDIEU, P. Questions de sociologie. Paris: Les Éditions de Minuit, 1988.

BOURDIEU, P.; CHAMBOREDON, J. C.; PASSERON, J. C. A construção do objeto. In: Ofício de sociólogo: metodologia da pesquisa na sociologia. 5. ed. Petrópolis: Vozes, 2004. p.45-72.

BOURDIEU, P. Que es hacer hablar a un autor? A propósito de Michel Foucault. In:

Capital cultural, escuela y espacio social. México: Siglo Veintiuno, 1997.

CLAUDE, S. O pai do bit. Disponível em:

$<$ http://www.mat.ufrgs.br/ portosil/shannon.html >. Acesso em: 15 maio 2012.

CAPURRO, R. Epistemologia da Ciência da Informação. In: ENCONTRO NACIONAL DE PESQUISA EM CIÊNCIA DA INFORMAÇÃO, 5., 2003, Belo Horizonte. Resumos... Belo Horizonte: ANCIB, 2003. Disponível em: <http://www.capurro.de/enancib_p.htm>. Acesso em: 14 maio 2018.

ECO, Humberto. A estrutura ausente. 7a ed. São Paulo: Perspectiva, 1997.

FIRKOWSK, H. Generalização cartográfica de grades retangulares regulares baseada na Teoria Matemática da Comunicação. 2002. 158f. Tese (Doutorado em Ciências Geodésicas) - Universidade Federal do Paraná, Curitiba, 2002. Disponível em: $<$ https://acervodigital.ufpr.br/bitstream/handle/1884/34998/T\%20\%20HENRIQUE\%20FIRKOWSKI.pdf?sequence=1\&isAllowed=y). Acesso em: 20 ago. 2012.

GUARALDO, T. S. B. Aspectos da pesquisa norte-americana em comunicação: primeira metade do Século XX. Disponivel em: <http://www.bocc.ubi.pt/pag/guaraldo-tamaraaspectos-da-pesquisa.pdf $>$. Acesso em: 15 maio 2012. 
MORIN, E. O método 1: a natureza da natureza. 2. ed. Tradução de Maria Gabriela Bragança. Mem Martins: Publicações Europa-America, 1977.

PELEGRINI, C. H. O significado contemporâneo da Teoria da Comunicação. Caderno.com, v. 4, n. 2, p. 11-23, 2009. Disponível em:

$<$ http://repositorio.uscs.edu.br/bitstream/123456789/116/2/Significado\%20Contemporaneo2 Cadernocom.pdf>. Acesso em: 15 maio 2012.

PIMENTEL, M. G.; ANDRADE, L. C. V. Educação á distancia: mecanismos para classificação e análise. Congresso Internacional de Educação á Distância, 7. ed. São Paulo: ABED, 2000.

PINEDA, J. O. A entropia segundo Claude Shannon: o desenvolvimento do conceito fundamental da Teoria da Informação. São Paulo: PUC, 2006.

PINHEIRO, L. V. R. Gênese da Ciência da informação ou sinais anunciadores da nova área. In: AQUINO, M. A. (Org.). O campo da Ciência da Informação: gênese, conexões e especificidades. João Pessoa: UFPB, 2002.

; LOUREIRO, J. M. Traçados e limites da Ciência da Informação. Ciência da Informação, v. 24, n. 1, 1995.

SARACEVIC, T. Ciência da informação: origem, evolução e relações. Perspec. Ci. Inf., v. 1, n. 1, p. 41-62, jan./jun. 1996.

SHANNON, C. E.; WAEVER, W. A teoria matemática da comunicação. Tradução de Orlando Agueda. São Paulo: DIFEL, 1975.

SLOANE, N. J. A.; WYNER, A. D. Claude E. Shannon: collected papers. Nova jersey: IEEE Information. Theory Society, 1993. 